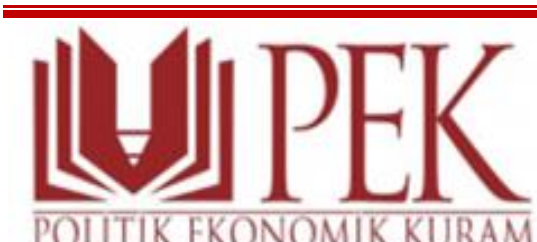

2020, Cilt 4, Sayı 2, 310-329

\section{POLITIK EKONOMIK KURAM}

E-ISSN: 2587-2567

https://dergipark.org.tr/tr/pub/pek

Doi: $10.30586 /$ pek.817746

Makale Geliş Tarihi: 28.10.2020

Makale Kabul Tarihi: 30.11.2020

Araştırma Makalesi

\title{
Kırsal Emeğin Dolayımında Aracı Formlar ve Egemenlik İlişkileri: Dünya Ekonomisinde Hane ve Emek Tartışması
}

\section{Intermediary Forms and Domination Relations in Mediation of Rural Labor: Discussion of Household and Labor in the World Economy}

\begin{abstract}
This study deals with Dynamics and paterns of household's flexible labour usage specifically in temporary agricultural Works. Especially the strategies in line with the household's minimizing risk and maximizing income porpuses have been dealt as a class analysis of the World-System perspective.

Households came forward with the coordination of the payment in cash and kind has been discussed as the sociopolitic bases of cheap and flexible labour supply. In line with the temporary agricultural labour, the intermediaries' efforts in establishing the brandnew temporary households from the members of the hauseholds in rural parts of the country and having them work have been examplified

This work depends on the findings from interviews with the temporary agricultural workers, intermediaries, employers, and admninistrative officiers during the 2017 and 2019 in Niğde and vicinity.
\end{abstract}

Keywords: Women Labour, Children Labour, Rural Household, Temporary Agricultural Workers

JEL Codes: J40, R20, R23

$\ddot{\mathbf{O z}}$

$\mathrm{Bu}$ çalışma geçici tarım işçiliği özelinde, hanelerin üyelerini esnek işgücü olarak kullanma dinamikleri ve örüntüleri ile ilgilenmektedir. Özellikle hanelerin riskleri minimize etme ve gelirlerini maksimize etme amaçlarına paralel olarak geliştirdikleri stratejiler, Dünya-Sistemi yaklaşımının sınıfsal analizi olarak ele alınmaya çalışılmıştır.

Ayni ve nakdi ücret ödeme biçimlerinin koordinasyonu ile öne çıkan haneler ucuz ve esnek işgücü arzının sosyopolitik temeli olarak ele alınmıştır. Geçici tarım işçiliği formuna uygun olarak, aracıların kırsal hanelerin üyelerinden geçici formda yeni haneler oluşturması ve bu haneleri çalıştırma sistemleri örneklendirilmiştir.

Çalışma 2017-2019 yılları arasında Niğde ve çevresindeki geçici tarım işçileri, işverenler, aracılar ve kurum yetkilileri ile yapılan ikili görüşmelerden elde edilen verilere dayandırılmaktadır.

Anahtar Kelimeler: Kadın emeği, Çocuk Emeği, Kırsal Hane, Geçici Tarım İşçiliği

\footnotetext{
${ }^{1}$ Dr. Öğr. Üyesi, Niğde Ömer Halisdemir Üniversitesi Sosyoloji Bölümü
} 


\section{Giriş}

Bu çalışma 2017-2019 yılları arasında Niğde ili ve ilçelerinde farklı zamanlarda yapılan saha ziyaretlerinde yapılan görüşme ve gözlemlerden elde edilen buylgulara dayanmaktadır. Dört ayrı ziyarette toplam iki devlet görevlisi, dört aracı, 17 hanereisi ve 19 erkek ve 47 kadından oluşan geçici tarım işçisi ile derinlemesine ikili görüşmeler yapılmıştır.

Çalışmamızın temel iddiası, emeğin sermaye tarafından kontrolünün her zaman doğrudan olmadığı ve bu ilişkinin hegemonik bir dolaylılık içerdiğidir. Genel geçer iddia içerisinde artı degere bağlı üretim ilişkilerinin her bir formunda emeğin özgür olmadığı çok fazla tartışılan bir konudur. Öte yandan tarımsal üretim ilişkilerinde emek ve sermaye, sanayi için öngörüldüğü şekliyle doğrudan bir ilişkiye asla girmemiş ve özellikle kırsal üretimde sosyopolitik bir dolayım olan patriarka üzerinden yürütülmüştür. ${ }^{2} \mathrm{Bu}$ patriarka, kadını ev-içi emek olarak kullanmaktan çok daha öte bir dolayımı barındırmaktadır. Hanenin patriarkal yapısı kapitalist üretim tarzının derinlemesine nüfuzu ile (Walby 1986, Hopkins 1982a ve b) doğru orantılı olarak kurulur ve kurulan hane içi ilişkiler birer eşitsiz güç ilişkisi formundadır. Bu eşitsiz güç ilişkileri, kendisini sınırlı kaynakların kullanımında toplumsal cinsiyet farkları olarak ortaya koyacaktır (Toksöz, 2012:87).

Burada konu olan dolayım ilişkisinin ne zaman, nasıl ve hangi formlarda nerelerde kurulduğudur. Dolayısı ile çalışmamız "küçük köylülük-küçük meta üretimi” dışındaki kapitalist üretim ilişkilerinin egemen genel bir yapıyı kapsamaktadır. Bu yapının içerisinde "ister doğrudan emek biçiminde, ister ürün biçiminde, ister ürünün eş değeri (para) biçiminde olsun, emeğin yarattığı değerin sermaye sahibiyle bölüşüm biçimi, üretim araçlarının mülkiyet biçimi tarafından belirlenmektedir (Erdost, 1988: 22)". Erdost "söz konusu kapitalist üretim ilişkisinin, yeni değer yaratma ve yaratılan bu yeni değerin üretim aracı sahibi (sermayedar) ile bölüşümüyle sınırlı olduğunu söyler (Erdost, 1988: 29).”

Bu çalışmada, mevcut üretim ilişkilerini sürdürülebilir kılan farklı ve daha karmaşık bir emek dolayımından bahsedip bahsedemeyeceğimiz, bahsedilebilirse temel çerçevesinin ekonomik veya kültürel dinamik ve örüntüler içerisinde ele alıp alamayacağımız tartışılacaktır. Bir başka deyişle, tarımsal üretim alanında emek ve sermayeyi doğrudan ilişki içerisine sokmadan kapitalist üretim ilişkisinin tarımsal üretimde geçici devamlılığını sağlayan aracı mekanizmaların neler olduğu ve bu mekanizmaların meşruiyetinin nereden geldiği çalışmamızın temel araştırma sorunsalını teşkil etmektedir.

\section{Kuramsal Arka Plan}

Dünya-ekonomi'si yaklaşımı, Immanuel Wallerstein ve John Terence Hopkins'in 16 yy.'da ortaya çıktığını iddia ettiği bütün ve sosyal bir sistem olarak Kapitalist Dünya-Ekonomi'sinin gelişme ve değişme dinamiklerini tartışan makro-sosyolojik bir yaklaşımdır. Özetle doğu'nun ve güneyin yaşadığı azgelişmişliği Batı'nın gelişmişliği - yani sömürüsü ile ilişkilendiren merkez-çevre tartışmalarının, 70'li yılların ilk çeyreğinde Fernand Braudel, Andre Gunder Frank, Terence Hopkins ve Immanuel Wallerstein tarafından ele alınan sistemli bir yaklaşımdır. Sonuçta Dünya-ekonomi'si, farklı ekonomik ve politik kuşaklarda (zonlarda ${ }^{3}$ ) üretim ve

\footnotetext{
${ }^{2}$ Burada "üretim araçları üzerindeki egemenliğin doğrudan mülkiyet ilişkileri üzerinden belirlendiği (Boratav, 2004: 20)" ve "sürecin parçaları arasında en egemen olanının emek olduğu görülecektir. Bu başatlığın "en önemli nedeni hangi araç olursa olsun emeğin dolayımına girilmeden, üretim bileşenlerinin kendiliğinden veya kendi başlarına değer yaratamayacakları gerçeğidir (Erdost, 1988:21).” Ama emek olgusunun kendi sosyal yapısı içerisinde kontrol edildiğini göz ardı etmemek gerekiyor.

${ }^{3}$ Dünya-sistemi literatürünün merkezinde olan merkez, yarı çevre ve çevre tartışması, bölge (region) veya alan (area) kavramlarından öte ilişkiselliğin kendisine işaret eden zone kavramı üzerinden yürütülmektedir. Bunun nedeni söz konusu üçlü tasnifin coğrafi bir kriterden öte ekonomi politik kriterlere göre yapılmış olmasıdır.
} 
tüketim ilişskilerinin işbölümüne dayalı olarak örgütlendiği bir bütün (totalite) olarak karşımıza çıar (I. M. Wallerstein, 1974).

Bu çalı̧̧mada, Dünya-Ekonomi'si merkez-çevre modellemesine dayanarak Türkiye'de batı ve doğu arasındaki tarımsal işgücü kullanımının ve emeğin kontrollü transferinin temel örüntü ve dinamikleri ele alınacaktır. Çalışmamıza uyarlanan temel teorik çerçevenin başında öncelikle Dünya-ekonomi'sinin gereği olan sonsuz sermaye birikiminin kendisini geçerli kılacak etkenler gelmektedir. Bu birikim, (i) Üretim maaliyetleri üzerinden rekabetin baskısı ile tekil kapitalist üreticileri farklı işgücü kaynaklarına ulaşma eğilimine yöneltir: Zira sonsuz sermaye birikimi öncelikle tek bir coğrafya içerisinde, tek bir kapitalist tarafından, ve tek bir işgücünün sömürülmesine indirgenemez; Birikim, (ii) Yerel işgücünün yarattığı artı-değerin sürekli olarak ve daha fazlasına el konularak gerçekleştirilemez. Zira emek sömürüsüne esas olan sermayenin organik bileşen oranının sermaye lehine sürekli değişimi esastır: Ve son olarak, (iii) ilk madde gereği doğrudan yereldeki emek-sermaye ilişkisine indirgeyemeyeceğimiz "eşit olmayan" bir artı değer değişimini zorunlu kılar. Bir başka deyişle "farklı ekonomik bölgelerde" (merkezçevre üzerinden batı-doğu aksında) bulunan "farklı nitelikteki" emeğin farklı düzeylerde sömürülmesi söz konusudur (Arghiri, 1972). Bu farklı sömürü, tarımsal üretim alanında kullanılan işgücünün geçici hareketliliği ile sermaye lehine 'eşit olmayan değişim' durumunu fiili olarak ortaya çıkarmaktadır. Bu durum, batıdaki ve doğudaki üretim araçlarının ayrı ve birbirinden bağımsız birer parça olmalarından değil her iki aksın bütünsel olarak kendi başına parçası olduğu bir ekonomi-dünya-ekonomi olmasından kaynaklanmaktadır.

Wallerstein'e göre kapitalizm -sonsuz sermaye birikimi üzerine kurulan ilişkilerin doğası gereği -bir sistem olarak farklı bir işgücünü entegre etmesi ve/ya söz konusu işgücünün olduğu çevre coğrafyalara uzanması üzerinden yürüyen bir sistemdir.

$\mathrm{Bu}$ anlamı ile herhangi bir coğrafyada kurulan kapitalist tarımsal üretim ilişkileri (i) işgücü olarak birbirleriyle bir kutuplaşma içerisinde var olabilen, (ii) birbirlerini var eden ve (iii) farklı artıdeğer üretimine dayanan bir ekonomiyi oluşturur (I. Wallerstein, 1982:92).

Modelde öngörüldüğ̈̈ gibi batı (Merkez) ekonomileri tam-proleter olma eğilimde olan daha fazla teknik/uzman/ücretli iş̧̧i sınıfina dayalı bir ekonomidir (I. Wallerstein, 1979:293). Kısmen veya tamamen kapitalist olmayan doğu (Çevre) ekonomisi ise daha çok üretiminde teknoloji konsantrasyonu gerektirmeyen meta üretiminde, emek yoğun ve tam olarak metalaşamamış nitelikteki ve sürekliliği olmayan işgücünü barındırma eğilimdendir. Kısmen veya tamamen kapitalist olmayan ekonomiler, emek karş̧llğı elde edilen gelirin ve emeğin kontrolünün tam olarak proleter bir formda yürütülmediği bir ekonomi olarak tanımlanmaktadır. Wallerstein, Dünya-ekonomi'sinin farklı kuşaklara genişleme

Coğrafi anlamda bölgeler, fiziki özellikleri üzerinden ve sadece bir başka bölgeye göre tanımlanmaktadır. Wallerstein, üçlemenin birinin diğerinden olduğu kadar her birisinin de kendi içerisinde, üretici güçleri, toplam hanehalkı gelirleri ve sermayenin birikim mentalitesi, yani üretim ilişkileri ile farklı olacağını söyler (Wallerstein 1983:30). Bir başka deyişle merkez-çevre ayrımı, dünyanın bir kısmına, bölgesine vs. işaret eden coğrafi bir bölümlenmeden ziyade bir bütünsel kuşak olarak, birinin diğerine göre veya içerisinde barındırdığı sosyal işbölümünün ilişkisel hiyerarşisi üzerinden tasnif edilmektedir. Zira Wallerstein bunu çok net ortaya koyar: "zone kavramı, ekonomik olarak karmaşık ve birleşik bir ilişkiselliği işaret ederken, "bölge" kavramı hanehalkının da içerisinde yer aldığı ve birincil ekonomik ilişkiler üzerinden tanımlanabilecek daha küçük bir birimi ifade etmektedir (Wallerstein and Smith 1992:21).” Dünya-sistemi literatüründe kullanılan zone kavramı yerine Türkçe çevirilerde kullanılan "bölge" kavramının yetersiz kaldığı düşünülerek "kuşak" kavramının kullanılması önerilmektedir. Çalışma boyunca, "kuşak" kavramı Zone anlamında kullanılacak olup aksi kullanımlar italik olarak belirtilecektir. 
rasyonalitesini, çevre ekonomilerde tam-proleter olmayan hanehalklarının ucuz işgücü sunma rasyonalitesine bağlamaktadır. Bir başka deyişle, çevre ekonomilerin kapitalist olmayan veya yarı proleter olan hanehalkı, tam proleter işgücünden ücretlilik durumu ile ayrıştığından çevre ekonomilerinin merkeze göre daha ucuz üretim yapabilmesi imkanı ortaya çıkmaktadır. Çevre ekonomileri, tüm üyelerin katılımıyla farklı kaynaklardan elde edilen gelirleri kontrol eden hane'nin ve hane'nin kontrol ettiği ve haneye bağımlı işgücünün (hanehalkı) varlığı ile sistem içerisindeki işbölümüne bağlanmaktadır (Tomich, 1990:43). Ellis hanehalk1 kavramlaştırmasını cinsiyet körlüğü ile suçlayarak haneiçerisinde gömülü olduğu güç ilişkilerini görüğnmez kıldığını iddia etmektedir (Ellis, 2008).

Hanehalkı kavramlaştırıması Dünya-ekonomi’si tartışmasına göre, bireyin ait olduğu biyolojik ve sosyal bağların bütünsel yapısını işaret ettiğinden sadece emek-sermaye karşıtlığında/n ve ücretlilik ilişkisinde/n ibaret olmayıp, üyelerinin emeğini kontrol edebilen küçük meta üreticisi niteliğindeki sosyal bir yapı olarak ele alınır (C. Chase-Dunn, 1983 and 1991). Bireysel faydayı kolektif çabada somutlaştıran hanehalkı kavramı, klasik anlamda iptidai bir formda kan bağına dayalı sosyal ilişkilerden ibaret ailevi türden bir birliktelik anlamına gelmemektedir. Hanehalkı, üyelerinin zorunlu bir akrabalık bağı ile bağlanmadığı gibi aynı mekanda ikamet etme şartının oluşmadığı sosyal bir yapıdır da aynı zamanda (I. Wallerstein, 2004:66). Söz konusu hanehalkı, bireylerin yaşamlarını sürdürebilmesi için gerekli temel kaynakları, çeşitli kanallardan temin ederek ortak olan bir havuzda toplayarak üyelerine ihtiyaç halinde sunabilen ve biyolojik olmaktan öte sosyal olarak örgütlenmiş temel bir birimdir (Friedman, 1984; I. Wallerstein \& Smith, 1992a). Bu anlamıla, hanehalk1, kapitalist Dünya-ekonomi'sinin operasyonel olarak yaratmış olduğu devlet, sınıf, statü-grupları vb. kurumlarından bir tanesi olarak ele alınmaktadır.

Bu kurumsallık, üç temelde hem işlevsel hem de enstrümantaldir. Öncelikle söz konusu sosyal grupların üyesi olan ücretli işgücü (klasik tanımıyla proleter), ulusal ekonomilerin kendi dinamiklerine veya ulusal ekonomilerin Dünya-ekonomi'si içerisindeki pozisyonlarına (uluslararasılık) göre değil, dünya olarak bir ekonomi içerisindeki konumlarına göre farklılıklar göstermektedir. İkincisi, Dünya-ekonomi'si açısından proleter kategorisinde toplanılabilecek tek ve homojen bir sınıfin varlığı ne işlevsel ne de enstrümantal olabilir. Son olarak, işgücünün kontrolü açısından merkez ve çevre ekonomilerindeki üretim ilişkilerinin kapitalist örgütlenişi ve kontrolü, klasik anlamda kapitalizm olarak değerlendirilen merkezdeki üretim ilişkileri ile aynı değildir. Dolayısıyla, kapitalist Dünya-ekonomi'si, biri diğerine bağımlı iki kutuplu sınıfın varlığ 1 ve sadece kapitalist üretim ilişkilerine bağlı tek bir gelir türü -ücretlilik teziyle açıklanabilecek ilişkilerden ibaret değildir.

Dünya-sistemi teorisyenleri emek tartışmalarında iki önemli yaklaşım üzerinden sınıf analizi yapmaktadırlar. İlk olarak emek kavramını gelir getirici bir aktivite olarak ele alırken gelir getirici faaliyetlerin sadece kapitalist -ücretli bir form ile sınırlandırılamayacağını ileri sürerler. Ploeg'in tartıştığı haliyle özellikle geçici tarım işçiliği, uzmanlaşmış, pazar yönelimli ve maaşlı işçilerden kurulu bir sistem olarak tasavvur edilir (Ploeg 2008). İkinci olarak kapitalist-dünyaekonomi'sinin sadece tam olarak ücrete bağımlı bir işgücünü (tam kapitalist hanehalkı) kullanarak sonsuz sermaye birikimini gerçekleştiremeyeceğini dolayısıyla yarı kapitalist hanehalkı kullanımının kaçınılmazlığını ileri sürerler. Tam tersine kâr realizasyonunu artıracak düşük işgücü maliyetleri, kısmi kapitalist veya hiç bir şekilde kapitalist olmayan, bir başka deyişle hanelerin toplam gelir maksimizasyonu ile düşük işgücü maliyetlerini sübvanse edebildiği hanehalkının kullanımıyla mümkün olabilecektir.

Burada birinci iddia, Dünya-ekonomi'sinde proleter sınıfın rasyonelliğinin, bir tek-başınalık içerisinde değil sosyal bir rasyonalitenin belirleyici olduğu bir çerçevede tartışılması gerektiği üzerinedir. Hanehalkı olarak tanımlanan bu sosyal topluluk, çeşitli gelir kaynaklarını kolektif 
olarak üyelerinin hayatlarını sürdürebilmek için uzun bir dönem boyunca, "gelir-havuzu ünitesinde" birleştirerek paylaşan bir grup insandan oluşmaktadır. Hanehalkı olarak tanımlanan bu sosyal grubun, gelecekte üyeleri için riskleri azaltma ve toplam hanehalkı gelirlerin maximizasyonu rasyonalitesiyle hareket ettiğini ve üyelerinin emek zamanların kolektif bir havuza aktararak her birisinin ihtiyaç duyduğunda diğerlerinin emek zamanından yararlanabileceği bir fayda sağladığını görüyoruz.

Sosyal rasyonalite olarak ortaya çıkan bu fayda, ancak hanehalkının her birisinin sürekli olarak bir ücrete bağlanmadığı, yani gelirin sadece üyelerin kendi yaşam boyu aktiviteleri için kullanma zorunluluğunun oluşmadığı durumlarda ortaya çıabilir. Böylesi bir hanehalkının toplam ücretlerden elde ettiği geliri, toplam ömür boyu elde ettiği gelirin bir kısmını oluşturur. Ağırlıklı olarak toplam hanehalkı geliri ücret-gelire bağlı olmadığ 1 için Wallerstein, bu haneyi yart-proleter hanehalkı olarak tanımlar. Bir diğer hanehalkı tipinde ise hanenin toplam ömür boyu gelirinin yüzde elli ya da daha fazlasını ücret-geliri oluşturur. Yaşam-boyu gerekli ücret, hanehalk1 üyelerinden birinin, hane dişında bir üretim sürecinde gerçekleştirdiği çalışma karşıllı̆ı̆nda, hanehalkı dışında bir birim tarafından yapılan, dönemsel ya da sürekli ödeme olarak değerlendirilmektedir (Wallerstein, 2004). Ağırlıklı olarak hanenin toplam geliri ücretgelire bağlı olduğu için Wallerstein, bu haneyi proleter hanehalkı olarak adlandırır. Ücret olgusu, çok farklı işlevlere ve formlara sahip olduğundan kapitalist birikim sürecinin devamlılığı ile doğrudan ilintilidir.

Bir üretim ilişkisinde özgür olduğu varsayılan işgücünün bir meta olarak alınıp satılabilmesi, kapitalist üretim biçimini diğer üretim biçimlerinden ayıran en temel göstergedir (Tomich, 1990:34). Fakat, Wallerstein sınıf ilişkilerinin ve sınıflar arası kutuplaşmanın, kapitalizmin yerelde tek taraflı ortaya çıkışından ibaret olmayıp, devletler-arası bir yapıda eş-zamanlı olarak değişen mekânsal ve zamansal ölçeklerde (Tomich, 1990:64) çoklu, ayrışık ve istikrasız olarak geliştiğini ve ortaya çıktığını ileri sürmektedir (Tomich, 1990:38). Bu yapı içerisinde, rasyonel olduğu öngörülen birey, yaşam boyu sadece ücret karşllığı elde edeceği gelire bağımlı olmadığı gibi sinıf örüntüsü de sadece yaşam boyu ücrete bağlı bireylerden ibaret değildir.

Dolayısıyla, bireyin, özellikle çevre ekonomilerde, sürekli tam-zamanlı ücretli iş̧̧i olmadığı iddias1 ortaya atılmaktadır. "Tam-proleter olmayan emek" ayrımı, bireyin harcamış olduğu sosyal emek zamanının her zaman paraya (ücrete) dönüşmediği durumların da olduğu anlamına gelmektedir. Söz konusu ücretin oluşmamış olması bireyin faydasının olmadığı anlamına gelmemektedir. Fakat bireyin faydası, bireyin kendisinin de çıkarını gözeten kolektif yapının -hanehalkının bir parçası olmaktan kaynaklanmaktadır. Bu fayda, bireyin kendi emek zamanını gelecekte ihtiyacı olduğunda kullanmak üzere bir başka üye için rezerve etme rasyonalitesinin temelini oluşturur.

Kapitalist-dünya ekonomisi, bu sosyal rasyonalite aracıllğıyla, iş gücünün bulunabilir ucuzluğunu ve ihtiyaç duyulduğunda kısa dönem emek arzını en üst seviyede tutmak için hanehalkı kurumunun işlevsel kullanımı yönünde sistemik bir baskı oluşturur (Wallerstein, Martin, \& Dickinson, 1982:438). Bu anlamda hanenin gelir getirici stratejileri, üyesi olan işgücünü yarı kapitalist ve kapitalist olmayan bir nitelikte tutmasına yardımcı olmaktadır.

\section{Toplam Gelir Stratejileri}

Daha önce değinildiği gibi, Wallerstein toplam gelir açısından işgücü ücretlerinin önemli olduğunu fakat belirleyici olmadığını ileri sürmektedir. Örneğin, ücretli emek formunda gelir olan bir ödemenin sadece nakdi olduğunun varsayılmasını doğru bulmamaktadır. Hanehalkının kısmi veya tam zamanlı olarak içerisinde olduğu üretim süreçlerinde ödemelerin çoğu zaman aynî formlarda da yapılabildiği görülmektedir. Bireyin emek zamanına karşıllık olarak yapılan 
ayni veya nakdi ödemeler, Wallerstein ve arkadaşlarına göre hanehalkının toplam gelir stratejisi açısından çok büyük değişiklik getirmemektedir. Ama bu esnek ödeme biçimi, kapitalist üretim zincirinde maliyetlerin azaltılması amacıyla kapitalist meta üretiminin sistemin bir parçası olan ve bu ödeme şeklini mümkün kılan ekonomilere kaydırılmasının en önemli nedenlerinden birisidir (I. Wallerstein et al., 1982:438).

Wallerstein hanehalkı açısından ücret gelirleri dışında elde edilen bir başka gelir türünün daha mevcut olduğunu ileri sürmektedir: "hayatı idame ettirmek için zorunlu olan şeylerin yapılması". Söz konusu çalışma, herhangi bir şey satın almaksızın hayatı sürdürmek için hanehalkının kendine yetecek şeyleri üretme faaliyetidir (I. Wallerstein, 2004). Bu faaliyet sıklıkla "geçimlik" faaliyetler olarak adlandırılır. Hanehalkının sahip olduğu ya da satın aldığı malzemeleri kullanarak, bunları dönüştürmek suretiyle ürettiği tüketim malları bu kategoride yer alır: çiftçilerin besin yetiştiriciliğinden, şehir işçilerinin pencere önü bahçeciliğine, orta sınıfın "kendin yap" faaliyetlerine kadar geniş bir faaliyet alanını kapsar (I. Wallerstein et al., 1982:438). Kapitalizmin giderek yerel ekonomilere nüfuzu ile azalmakla birlikte, yiyecek tüketimini düzenlemek amacıyla yapılan avcılık toplayıcılık ve tarımsal çalışmalar da bu kapsamdadır. Ayrıca, hanehalkının kendisi için alkol üretimi ve elbise dikimi ve onarımı, giderek daha önemli bir gelir kaynağı olarak kendisini göstermektedir. Hemen hemen tüm hanehalkı, yeniden üretim olarak bu gelir türüne yaşamlarının bir noktasında bağımlıdır.

Üçüncü tür gelir kaynağı, geçimlik faaliyetleri de kapsayan küçük meta üretimidir. Bu üretim azgelişmiş ekseninde ekonomik açmaza bir çözüm stratejisi olarak tartış1lıyordu (Bernstein, 2009). Hanehalkı sınırları içinde üretilen ve geniş bir pazarda nakit para karşılığı satılan ürünlerden elde edilen gelir kaynağıdır. Bu üretimin ayırıcı özelliği artı değer elde edilmekle birlikte üretim ilişkisinin kapitalist formda olmamasıdır. Marx bu tür üretimi, üretim ilişkilerinin köklü değişimlerinde henüz ortadan kalkmamış ikili nitelikte olan ilişki olarak tanımlar. Hızlı bir şekilde kapitalizmin tam anlamıyla gelişimiyle birlikte feodal nitelikte olan bu ilişkinin terk edileceğini öngörür. Bu yalnız üretilmiş malların pazarlanmasını değil, küçük pazarlama işlerini de içerir. Entelektüel mallar da bu grubun içindedir. Bu gelir türünde Marx artı değeri yaratanın artı değere el koyabilmesini, üretim araçlarına sahip olmasına bağlamaktadır. Üretim araçlarından yoksun kalındığında artı değer üzerinden sömürü ilişkisinin gerçekleşeceğini öngörür. Fakat Wallerstein, bir hanehalkı stratejisi olarak çok ucuza çalıştırılan bir üyesinin elde edeceği gelirden kaybını -mülkiyet ilişkisine ek olarak hanehalkının toplam gelir (artı değer) havuzundan sübvanse etmesine de bağlamaktadır. Hanehalkının toplam geliri olmadan üretim araçlarına sahip olanın her zaman yeterli düzeyde artı değere el koyamayacağını söyler.

Hanehalkı gelir stratejisinin bir başka dayanağı olan gelir ise ranttır. Ricardo'nun tanımıyla rant, hane halkının yasal olarak mülkiyetinde olan çoğaltılamayan malların kıtlığından kaynaklanan ve hanehalkı dışında herhangi birisi tarafından bu malların kullanılmasından elde edilen gelirden alınan paydır. Fakat Dünya-sistemi yaklaşımında, yasal mülkiyeti hanede olan ama hane tarafından kullanılmak üzere bir başka kişiye veya kuruma devredilen tüm varlıklardan elde edilen kira, faiz, menkul kıymetler borsa gelirleri vb. tüm gelirler de bu grupta kabul edilmektedir. Sermaye yatırımı ya da sermaye gelirinden elde edilen kazanç, ilk bakışta teorik olarak sermayenin kapitalist ekonomik sürece dahil edilmesi olarak tartışılabilir. Ama Wallerstein ve Smith (I. Wallerstein \& Smith, 1992b) sermaye sahibinin gelirinin klasik anlamda ücret olarak tanımlanamayacağını ile sürer. Pratik anlamda bu gelir türü klasik anlamda çoğaltılamayan mallardan elde edilen gelir türüyle eş değer niteliktedir.

Son olarak ücretli formda olmayan gelir türünden sayılan transfer ödemeleri olarak adlandırılan bir gelir türü daha vardır ki karşılığında sosyal emek zamanı gerektirmez. Transfer ödemeleri, doğum, evlenme veya ölüm gibi zamanlarda bir kuşağın başka bir kuşağa hediye ya da borç 
vermesi suretiyle elde edilen gelirdir. Bu gelir türü bireysel düzeyde olabileceği gibi komünal düzeyde de olabilir. Sigorta sistemiyle elde edilen gelir de transfer ödemesi olarak kabul edilir. Bu süreçlerin sonunda kişi fayda da sağlayabilir, zarara da uğrayabilir. Fakat her durumda bu gelir türü, hanehalkı gelir maximizasyonu stratejilerinde hatır sayılır bir hesaplanılabilirlik ve öngörülebilirliğe sahiptir.

İlk bakışta ücretler dışında olan bu gelir getirici aktivitelerin, kapitalist üretim ilişkileri açısından bir önemi olmadığı ileri sürülebilir. Zira ücret durumu, klasik anlayışta kapitalist üretim ilişkisinin olası tek gelir getirici ilişkisi olarak ele alınmaktadır. Bu durumda minimum ücret, en basit anlamda bir işçinin yaşamını devam ettirebilmesi için gerekli olan ücret olarak tanımlanmaktadır. Herhangi bir hanenin, üyelerinin tamamının yaşam boyu ücretli işçi olması elbette hanenin veya ailenin gelir seviyesini artıracaktır (I. Wallerstein, 1982:96).

Fakat kapitalist sistemin sonsuz sermaye birikimi eğilimi, sermayenin organik bileşenleri üzerindeki baskıyı artırarak ücretlerin sürekli olarak düşürülmesini gerektirir. Bu anlamda daha çok merkez ekonomilerde görülen tam-proleter haneler kapitalizmin kendisini gerçekleştirmesi önünde bir engel teşkil eder. Wallerstein herhangi bir bireyin ait olduğu bir hane içerisinde bir başka birey ile birlikte gelirlerin maximizasyonu ve risklerin minimizasyonu rasyonalitesi ile yaşamı ortaklaşa yürüttüklerini, dolayısıyla hanenin farklı gelir kaynaklarını mobilize ederken en az bir veya birden fazla üyesini hane içi emek olarak kullanılması için boşa çıkarabildiğini ileri sürmektedir.

Wallerstein'e göre yukarıdaki farklı gelir türleri, büyük bir işgücü kaynağının hanenin kendi kaynakları ile yaratılması anlamına gelmektedir. Zira hanelerin toplam gelir elde etme stratejileri üyelerinin temel ihtiyaçlarını karşılayabildiğinden, üyelerinin zaman zaman ucuz işgücü olarak sermayenin emrinde çalışabilmesine zemin hazırlamaktadır. Farklı gelir kaynaklarını mobilize edebilen bir hanehalkı, herhangi bir üyesini minimum ücret gözetmeksizin kısa süreliğine veya düşük ücretle bir üretim sürecine yönlendirebilir. İşgücü maliyetinin, geçici ve/ya ücret gelirine doğrudan bağımlı olmayan bir işgücü tarafindan düşürülmesi, aynı zamanda herhangi bir üyesini ücretli olarak işe gönderen bir hanehalkının de üretim sürecinde kapitalistlere karşılığını almaksızın çalışmış sayılacağı anlamına gelir (I. Wallerstein, 1982:97). Bu anlamda tam kapitalist olmayan işgücü, Dünya-ekonomi'sinin sonsuz sermaye birikimi için gerekli olan ucuz işgücü anlamına gelmektedir.

Kırsal alandaki mevcut bulunan üretim biçimleri dikkatle incelendiğinde hanelerin iki başat özelliği dikkat çekmektedir: Kendisi için üretim ve piyasa için üretim. Birincisinin ikincisi için önkoşul olduğu bu üretimlerden her ikisini de yapabilmek, kırsal hane üyelerinin tamamıyla emek piyasasına eklemlenmeyerek hane içi emek olarak üretime katılmaları ile mümkün olmaktadır. Ancak Köylülük, ilkesel olarak geçimlik üretim yapma sinırlılığı ile ele alınmaktadır (Kılıçbay, 1985, Geçgin, 2009). Kılıçbay, köylülügün yeniden üretimini sağlayacak optimal bir büyüklügün gerekli olduğunu söylemektedir. Fakat köylü giderek topraksızlaşma ile karşı karşıya kalarak proleterleşme eğilimine girer (Candan vd., 2013). Boratav ise küçük meta üretimi ile köylünün, emek olarak sermaye ile üretim ilişkisine girdiğini söyler (Boratav, 2011). Bu ilişkinin zorunluluğu ise köylünün toprak büyüklügüü dışında işletme sermayesinden yoksun oluşu ile de doğrudan ilintilidir. Ayrıca "kullanılan teknoloji, ücretli iş gücü kullanımı, ürün türü gibi ekonomik ve sosyal göstergeler de birer tabakalama ölçütü olarak kullanılabilmektedir (Altan, 1987:38)." Fakat ikinci üretimin her zaman gerçekleşmesinin, köylü hanelerin sermaye olanaksızlığı nedeniyle mümkün olmadığını görüyoruz. "Sahip olunan toprak, özellikle bizim çalışma alanımızdaki köylü hanelerini doyurmaktan ve köylünün yeniden üretimini organize edebilmekten çok uzaktır (Gülçubuk 2012)." Dolayısıyla köylünün toprağa dair yatırımı, genellikle niteliksel bir dönüşüme yol açmayan hane-içi emek miktarı ile sınırlı bulunmaktadır. 
Hem geçimlik hem de piyasa odaklı üretimi mümkün kılan toprağın köylü ve rantiyer arasındaki kısmi olararak orantısız paylaşımı, kırsal alandaki emeği sahip olduğu toprağında "geçimlik-gereklilik" amacıyla ve sahip olmadığı topraklarda ise artık-ürüne bağlı olarak şekillendirmektedir (Kula, 1985). Dolayısıyla "köylü, piyasa ile üretici olarak çok kısıtlı bir ilişki içerisindedir (Kula, 1985:64).” Kulaya göre girebileceği ilişki, genellikle sahip olmadığ1 topraktaki üretim ile sinırlıdır. Hanede mevcut kişi sayısı fazladır, hane büyüklüğü beklenildiğği şekliyle Türkiye ortalamasından fazladır (Benek ve Ökten, 2011; Kula, 1985; Semerci vd. 2014; Toksöz, 2012; Uysal ve Kesim, 2014; Yıldırak vd. 2009). Bu ilişkiden elde edilen gelir, bir yandan köylünün az miktardaki toprağından ve/ya üretimin mevsimselliğinden kaynaklanan daralan geçimlik ekonominin eksiğini giderecek diğer yandan da kırsal hanenin işgücü olarak yeniden üretilebilirliğini mümkün kılacak bir kaynak olarak görülür. Dolayısıyla köylülügün yeniden üretimini sağlayan, ileri sürüldügü gibi optimal bir büyüklükten daha çok emek gücünün hane kontrolünde artı değer üretimine entegre olmasıdır.

$\mathrm{Bu}$ çalışma kırsal hanelerin kendilerini yeniden üretebilmeleri açısından tarımsal üretim sürecindeki geçici bileşenler olan emek ile sermayenin arasındaki ilişkinin kuruluş örüntülerini ve dinamiklerini anlamayı amaçlamaktadır. Bu ilişkinin liberal postulada öngörüldügü gibi özgür emeğe ve/ya rekabete bağlı rasyonel formda oluşmadığı, bu çalışmanın gerekliliğini aleni şekilde ortaya koymaktadır.

\section{Tarımda Kadın Emeği Sorunsalı}

Sanayi alanında olduğu gibi elbette kapitalist tarımda da emek gücünün cinsiyetçi bölünümü üzerinden sermayenin çıkarının en üst seviyede tutulması kapitalist üretim ilişkilerinin ekonomipolitiği gereğidir (Standing, 1989; Razavi, 1999). Hane içi emeğin cinsiyetçi yapıs1, güvencesiz emek formunu ortaya çıkarırken aynı zamanda da güvencesizlik üzerinden diğer etkenlerin de belirleyici olduğu çoklu ayrımcılık durumunu ortaya çıkarmaktadır (Nurol ve Ünal; 2018:59). Çalışmamızda, tarımsal alandaki üretim ilişkilerinin, yapılan işlerden elde edilecek olası verimle ilintilendirilerek, büyük oranda kadın ve/ya çocuk emeği üzerinden sürdürüldügünü biliyoruz. Bu çalışmada öncelikle emek bahsi geçtiğinde çocuk ve kadın emeğini, çocuk ve kadın emeği bahsi geçtiğinde de en ucuz (Illkkaracan ve Tunalı) hane içi emeği kastediyor olduğumuzu belirtmeliyiz. "Tarlada, evde yoğun emek harcayan kadınların toplumsal konumları "ücretsiz aile işçisi”" olarak tanımlanır (Sirman, 1991:30)." "Tarım sektöründe çalışan mevsimlik tarım işçisi ailelerin en temel ayırıcı özelliği topraksız/mülksüz olmalarıdır (2011, aktaran Candan ve Günal, 2013)." Fakat bu durum, kadının emeğinin olası verimiliğini temel alan sanayi üretimindeki gibi kadının işçi olarak üretim ilişkisine üretimin belirleyici öznesi olarak sokulmasını kaçınılmaz kılmamaktadır. Dolayısıyla, ilk açıklamanın gereği olarak, tarım alanında üretim ilişkilerinin gerçekleşmesinde emeğin ekonomi-politiğine ek olarak emeğin sosyo-politiğinden de bahsetmenin bir ihtiyaç olduğunu belirtmek gerekiyor.

Yapılan derinlemesine ikili görüşmelerde kadının, sermaye karşısında doğrudan birer özne (emek) olmaktan öte sosyo-kültürel dinamiklerle, özellikle hane reisi erkeğin (koca veya baba formu dahil olmakla birlikte bunun dışındaki erkeklik formları da geçerlidir) aracılığıyla, dolayıma giren üretimin aracı enstrumanlarından birisi haline getirildiği ortaya konulmuştur. Sözü edilen kadın emeği, feodal bir formda dolaysız olarak sermaye ile ilişkiye giremeyen ve bundadn dolayı da ekonomi-politik içerisinde meşruluğu konu edilmeyen bir tür emek olarak değerlendirilmektedir. Bu emek türü, sermaye ile gerek ücret gerekse sömürü ilişkisine dolaysız ve kendi kontrolünde ve isteği ile giremezken değeri ürettiği iddia edilen emek türü olarak, patriarkal yapının sosyopolitik denetlemesi, kontrolü ve tasarrufu ile şekillenmektedir (Geçgin, 2009). Geçgin'ın konu ettiği yapı, erkeğin kadın emeğini ele geçirme ve kontrol etme biçimi olarak "feodal" formu göstermekle beraber tam olarak kapitalist formdaki bir üretim 
biçiminin merkezinde yer bulmaktadır. "Ekonomipolitik kapsamında kurulan mülkiyet ilişkisi, doğrudan emekçinin, üretim araçları sahibi karşısındaki bağımlılığının özelliklerini ve sınırlarını belirlerken" (Erdost, 1988: 22)," sosyo-kültürel formun egemen yapısı da sermayeden önce kadının erkeğe göre sınırlılıklarını ve ona bağımlılığını belirlemektedir.

Ataerkil anlamda, kadın emeğinin ne tür bir formda işbölümü dolayımına tabii olacğaını ve bu işbölümünde kadın tarafından yaratılan artı değere nasıl el konulabileceğini, mevcut toplumsal yapılar ve egemen kültürel formlar belirlemektedir. Bir başka deyişle, kapitalist üretim ilişkisinde ortaya çıkarılan artık değere el konulma sürecinin, mevcut toplumsal ve kültürel çerçevede kurulu egemenlik ilişkilerden ayrı bir ilişki formu içerisinde değerlendirilmemesi gerekmektedir. Geçgin çalışmasında sömürü, dışlama ve egemenlik ilişkilerinde bileşenlerin birbirinden izole edilmiş alanlarda gerçekleşemeyeceğini haklı olarak tartışır. Dolayısı ile özel alan olarak ayırmaya kalktığımız hane içi ilişkiler ile emeğin doğrudan üretim ilişkisine girdiği alanı birbirinden ayırmak mümkün değildir. Bu bağlamda, toplumun genel yargısına paralel olan aile formunun, cinsiyet modellerine dayalı kurulu ve ailenin kendisini sosyal bir birim olarak yeniden üretmesinde etkin olmuş bir hane-içi işbölümüne bağlı olduğunun altını çizmemiz gerekiyor. Buna ek olarak hane içi işbölümünün hem bir sonucu hem de bir nedeni olarak, hane içi hiyerarşik ilişkilerin bireyin her türlü ediminde belirleyici olduğunu da belirtmekte fayda var. Dedeoğlu çalışmasında bu hane içi eşitlenemeyen ilişkilerin, "ailenin devamlılı̆̆ını sağlamaya ilişkin üretim, yeniden-üretim gibi faaliyetlerin" ve varolan gelirlerin ve kaynakların aile bireyleri arasında dağılımının da eşitsiz olmasına neden olduğunu tartışır (Dedeoglu 2018:141).

Fakat söz konusu eşitsizliğin salt özel alanın düzenlenmesinden ibaret olmadığının da altının çizilmesi gerekmektedir. Bir başka deyişle, hiyerarşiye dayalı emeğin dolayımındaki sömürü ve egemenlik ilişkisi, ilk elden ve sadece özel alanda yürütülüyor değildir. Ya da daha genel ifadesiyle emek ve sömürünün toplumsal kodlarla sürdürüldüğü alan, aslında sadece özel olarak tanımlanamaz. Sahadan elde ettiğimiz bilgiler 1şığında, üretim ilişkilerinde emek-sermaye ilişkisine ek olarak emeğin kendi bileşenlerine ayrıldığında zihin (aracılık)-beden (doğrudan emek) ilişkisinin de var olduğunu ve bunun da ilki kadar "emeğe el koyma" üzerinden kurulduğunu söyleyebiliriz. Bir başka deyişle " sadece ev içinde ve ev dişında (Hart, 1995: 41)" birbirinden ayrı alanlarda değil, her ikisinin de hem neden hem de sonuç olduğu eşzamanlı etkileşimsellik formunda kurulduğu ortadadır.

Akrabalık ilişkileri, cinsiyete dayalı işbölümü ve patriyarkal ilişkilerin sadece sosyal yaşamın yeniden üretimini sağlayan özel hayatı değil (Dedeoglu 141), aynı zamanda kültürün dolayımı ile üretim ilişkilerini de organize ettiğini görüyoruz (Daly, 1989; Payne, 1991; Ruspini, 1999). Bunun tersi de aynı derecede geçerlidir.

Hanede varolan kadının potansiyel emeği, ücretsiz işçi olarak ev-içi yeniden üretimden sorumlu iken, aynı zamanda da boş zaman faaliyeti gibi yanlış bir algıya tabii olan ve aileye ek ücret getiren faaliyetlerde de kullanılmaktadır (Kabeer, 1994). Kadının hane gelirine katkısı tartışmaları hep boş zamanın değerlendirilmesi aksı üzerinden yürütülmektedir. Klasik bir algıyla, ailenin kontrolünde bulunan emeğin çeşitli faaliyetler arasındaki rasyonel dağılımından bahsedilmektedir. Bu Kula'nın, kırsal hane emeğini türdeş olmayan emek olarak tanımlaması ile daha da belirginleşir. Özellikle mevsimsel dönemlerde bu türdeş olmayan emeğin birisinin -erkeğin- geçci olarak sanayi içerisinde kullanımda olduğunu dolayısıyla tarımsal geçici üretimin ve işçiliğin kadın tarafından üstlenilme zorunluluğunun altı çizilir (Kula, 1985:73). $\mathrm{Bu}$ varsayım, kararların aile içinde birlikte ve eşitlikçi bir temelde alındığı varsayımına dayanır ki o zaman hanenin kontrolündeki emek nosyonuna karşıt bir arguman geliştirmiş oluruz. Hanenin ataerkil yapısı aracılığıyla kurulan hane içi ilişkiler birer eşitsiz güç ilişkisi formundadır. $\mathrm{Bu}$ eşitsiz güç ilişkileri, kendisini sınırlı kaynakların kullanımında toplumsal 
cinsiyet farkları olarak ortaya koyacaktır (Toksöz, 2012:87). Burada bu birlikteliğin ve eşitliğin geçerliliğini ölçebilmenin tek yolu emeğin yarattığı artı değerin nasıl kullanıldığının analizidir. Piyasa faaliyetlerine katılmayan, dolayısıyla da klasik ekonomik yaklaşımın tabiriyle değişim değeri üretmeyen kadın emeği, hane emeği olarak geçici tarım işçiliğinde üretim ilişkilerine girdiğinde (Aydın 2002) üretilen değerin nasıl kullanıldığı önem taşımaktadır.

Çalışmamızda elde edilen bulgulara dayanarak hane içi yeniden üretim ilişkilerine değil hane dışı üretimde yaratılan değerin kullanımına bakılarak geçici tarım işçi hanelerinde bütün üretim karar mekanizmalarının erkek denetiminde yürüyor olduğunu söyleyebiliyoruz. Geçici tarım işçiliğinde kadın sadece kullanım değerinin üretimi ile sınırlı olmadığı gibi erkek de sadece değişim değeri üreten tek cinsiyet olmamasına ragmen, artı degere el konuluş biçiminde bir değişme gözlemlenmemektedir. Bir başka deyişle, hane içi ile sınırlı olan kadın emeği sermaye ile bir değişim değeri üretme ilişkisine girdiği halde üretken kabul edilmemektedir.

Dolayısıyla, özellikle üretim ilişkilerinin kuruluşunda rasyonellik olgusununun dışında başka belirleyicilerin olduğunu da düşünmemiz gerekiyor. Kandiyoti'nin ifadesiyle partiyarkal aile, ev kadını formunda kadının emeğini ve katkısını görünmez kılarken hane dışında da kadının emeğine doğrudan el koymaktadır (Kandiyoti, 1988: 279). Bu el koyma geçici tarım işçiliğinde kadının gelirine dolaylı olarak el koymanın ötesinde, sosyopolitik bir formda oluşmaktadır. $\mathrm{Bu}$ sosyopolitik form kendisini en geniş ifade ile, erkeğin kadın emeğini bizzat kendi dolayımı ile sermayeye sunarak gelirine doğrudan hane geliri olarak el koymasında gösterir.

Bir başka deyişle buradaki tespitimiz geçici tarım işçiliğinde aracılık ilişkisinin sadece sermaye ile emek arasındaki bilindik aracıları kapsamadığı ve önemli aracılık formunun baba-eş konumu ile sınırlı olmayan hanereisi tarafından yürütüldüğüdür. Kadının emeği değer yaratmak üzere doğrudan emek-sermaye ilişkisine alınmak yerine, kendisi adına hanereisinin aracılığıyla sosyopolitik yapı üzerin/e/den kullanıma sunulmaktadır. Sonraki bölümde ilk elden klasik aracı formların oluşum ve işleyiş̧ini detaylandıracağız. Takip eden bölümde ise aracılık ilişkilerinin sosyo-politik dinamiklerine odaklanılacak.

\section{Tarımda Aracılık Formlarının Ekonomi Politiği: Hanereisi Olarak Çavuş}

Geçici tarım işçileri ile ilgili olarak yapılan çalışmaların tamamına yakınında aracılık ilişkilerinin sermaye ile emek ikilisi arasında geliştirildiği tespiti yapılmaktadır. Fakat çalışmamızın iddiası; aracılık formlarının emek-sermaye ekseninden hanereisi formuna yükselerek emeğin sosyal ve politik kontrolünü de sağlayabildiğidir. Bir başka deyişle aracılık mekanizması -çavuşluk, hem emek-sermaye ilişkisi hem de birey-hanereisi ilişkisi formunda tarımsal geçici emeği kontrol etm ektedir. Dolayısıyla, aracılık ilişkilerinin talip olduğu işlevlerin sadece işin bitirilmesiyle sınırlı olmayacağını da söylemeliyiz. Aracılık sistemine atfedilen en önemli işlev, daha çok kurumsal olup işgücü arzında veya talebinde karşılaşılan sorunların giderilmesidir. Çalışmamızda bu oldukça belirgin bir durumdur. Örneğin bağımsız çalışan ailelerin geldikleri bölgede hemen iş bulamayarak bütçeleri için hatırı sayılır bir süre işsiz kalarak birikimlerinden harcama riskleri, aileyi emek-sermaye ilişkileri kapsamında bağımsız çalışma yerine aracılık sistemine dahil etmektedir. Gelen'in çalışması hane üyelerinin çavuşun ekibinde ve emrinde çalışmasının daha çok karlı ve güvenli görüldüğünün altını çizmektedir (Gelen, 2008:96).

Tarımda geçici emeğin aracılık sisteminde sürüdürülüyor olmasının tek gerekçesi iş-güvencesi değildir elbette. "Talep ve arzın yönetimi olarak adlandırabileceğimiz bu işlev, bölgelere göre değişmekle birlikte dayıbaşı, elci, veya çavuş formlarında yerine getirilmektedir (Karaman ve Yılmaz, 2011:224)." Karaman ve Yılmaz bu aracıların işçi ve işverenden belli miktarlarda komisyon alarak arabuluculuk hizmetleri verdiğini ve "işveren için işçi, işçi için ise iş ve ücret garantörü” olarak görüldügünü belirtmektedirler (Karaman ve Y1lmaz, 2011:224: Gelen, 
2008:95). Söz konusu işlevler, bizim çalışmamızda da işin temel yapısını oluşturmakta ve geçici tarım işçilerinin iş bulmaları, çalışma alanlarına ulaşımları ve ek olarak orada konaklamaları ve yapılması gereken işin niteliğinin bilinmesi ve kontrolü gibi işleri kapsamaktadir. ${ }^{4}$

\section{a. Ekonomik Anlamda Bă̆ımlılı İlişkisi: Nakdi-Ayni Kredi Sistemi}

Söz konusu aracılık hizmetlerinin işlevleri detaylandırıldığında, daha farklı işlevlerin görünmez bir şekilde ilişkilere içkin olarak yerleşmiş olduğu görülmektedir. Bu görünmeyen işlevler, bir teamül oluşturmuş ve ilişkilere içkin olarak daha çok bir güven merkezli karşılıklı bağlayıcılık üzerinden harekete dönüşmüştür. Bu karş1lıklı güven ve zorunluluk ilişkisi emek sömürüsünü artıracak şekilde çavuşu araci konumundan aynı zamanda hanereisi konumuna da yükseltmektedir. Güven odaklı karşılıklılık formunda kurulu bağlayıcılık ilişkisinin iki temel ayağı bulunmaktadır. Birincisi ayakta ilişki Çavuş ile işveren arasında kurulmakta ikincisinde ise çavuş ile hane reisi veya çavuşun bildiği tanıdığı veya akraba olduğu diğer hane üyeleri ile birlikte yeni oluşturulacak ortak amaçlı çalışma hanesinin üyeleri -arasında kurulmaktadır. Her iki durumda da ilişki güven temelli kurulmakla birlikte az ya da çok emeğin ipoteğini getirmektedir.

\section{i.Çavuş-İşveren İlişkisi}

İlk savımız, iş için gereken emek gücünün zamanında (on-time) ve yerinde (in-time) temininin görünmeyen ikili ilişkilerin aynı anda hem birer nedeni hem de birer sonucu olarak ele alınması gereğidir. Böyle bir ilişkide, üretim dışı kalan kişisel ilişkilerine bağlı olarak işverenenin çavuşa kısmi veya tam avans vermesi ve böylece kısmen gelecekte yapılması öngörülen üretimde işveren için ihtiyaç olan işgücü kullanımının hazır hale getirilmesi durumu bir çok çalışmada görülmektedir. Karaman ve Yılmaz'ın çalışması, "dayıbaşı gibi aracıların işveren ile iş anlaşmalarını işverenden avans alarak çoğunlukla sezon öncesinde sözlü olarak yaptıklarını göstermektedir (Karaman ve Yılmaz, 2011:219).” Bu, kurulu güven ilişkilerinin aracılık sisteminde ne kadar önemli olduğunu göstermektedir. Fakat, bu ilişkilerin süreklilik arzetmesi güven ilişkisinin sürekli olarak test edilen bir ilişki olması ile doğrudan ilintilidir. Çavuşİşveren arasındaki bir avans ilişkisinin yer almaması, söz konusu güven ilişkisinin olmadığ anlamına gelmemektedir. Bir başka deyişle avans ilişkisinin, üretim ilişkisini tek başına sistemleştiren bir güce sahip olmadığının altını çizmekte fayda var. İşlev olarak kabul ettiğimiz işgücü arzının stabilize edilmesi, avans dışında da devamlılığını sürdüren bir güven ilişkisinin sonucudur. Üretim ilişkisinde önemli bir işlevi olan güven, avans sistemine ek olarak tesis edildiği gündelik yaşamda sürekli olarak test edilmektedir. Güven, soyut bir tercihler bütünü değil, tercihleri belirleyen somut bir ilişki bütünü olarak ortaya çıkmaktadır. Güven, kuruluşundaki ihtiyaça ve karşılıklı çıkara bağlı olarak sürekli yenilenen ve aracı ile işverenin amaçlarını gözeten bir ilişki üzerinden somutlaştırılmaktadır.

Ben telefon ediyorum kaç işçi gerekiyor. Buradakiler (işveren) söyler. Daha önceden biliriz birbirimizi. Ben yirmi beş otuz yıldır bu işi yapıyorum hiç sorun çıkarmadım. Önceden yüz çadır getirirdim. Buralar hep benim işçim ile dolardı (Adıyamanlı Recep Çavuş, 40,Konaklı)

Öte yandan çalışmamızda işin karşılığı olan ücreti vermeyen işverene rastlanılmadığ gibi, gerek çavuşların gerekse aracılı-aracısız çalışan işçinin paralarını alamayacağı yönünde bir algı

\footnotetext{
${ }^{4}$ Bu tür aracılık hizmetleri yasal bir düzenlemeye de konu olmuş ve "Tarımda İş Aracılığı Yönetmeliği" 2010 yılında resmi olarak düzenlenmiştir.
} 
da tespit edilmemiştir. Bu durum, aracıdan daha çok işverenin ihtiyaç duyduğu işgücünün sürekliliğinde ve kontrolündeki güven ihtiyacına zarar verecektir. Zaman zaman başka çalışmalarda işverenlerin çavuşlara avans olarak nakdi ödeme yaptı̆̆ bilinmekle birlikte bizim örneğimizde daha çok ayni ödemelerde bulunduğu da tespit edilmiştir. Fakat bu ilişkinin sömürünün daha çok artmasına dönük olarak doğrudan ve küçük de olsa bir katkısının olduğunu düşünüyoruz. Çavuş-işveren ilişkisinin dostluk formunda duygusal emek ilişkilerine taşınması en fazla yapılacak işin temiz yapılması ve nadir olmayan küçük ekstraların yerine getirilmesine yol açabilmektedir.

Avans sistemini takiben öngörülen sömürü, daha çok hane reisi aracıllğında veya doğrudan kurulan Çavuş-Hane Reisi ilişkisinde hali hazırda işverenin lehine mevcut olan üretim ilişkisi olarak kurulmaktadır.

\section{ii.Aract-Hane Reisi İlişkisi}

Sosyal sermaye bağlamında kurulan artı değere el koyma biçimlerinin mevcudiyeti öncelikle aracı ile geçici tarım işçileri hanelerinin akrabalığında gizlidir. Bu akrabalık aynı zamanda hanereisi kavramlaştırmasını da yeniden ele almamıza neden olmaktadır. "Tefeciler, ağalar, elçiler genelde bölge insanı ya da köylülerden birisidir. Böyle olunca aracı-işçi arasındaki ilişkiler, kanbağı-hukuki yükümlülükten çok toplumsal kaynaklı olmaktadır (Kaleci 2007: 27).” Fakat daha da önemlisi, emeğin sömürüsünü kontrol eden aracı ile doğrudan kanbağına sahip olmayan hane reisi arasında mevcut olan avans ilişkisinin kurulmuş olmasıdır.

Çalışmamızda da aracının kanbağına doğrudan sahip olan (eş-baba) hane reislerine yaptığı nakdi avans ödemesinin, genellikle daha önce kurulan iş ilişkileri, akrabalık, veya kurulan sosyal network aracılığıyla yürütüldüğünü görmekteyiz. "Mevsimlik tarım işçilerinin yazın yapılacak işlere karşılık kışın avans alması da yaygın bir uygulamadır (Kaleci, 2004:49).”

Özellikle çalışma dışı olan kış zamanlarında hanelerin ani ihtiyacını veya eksik kalan geçimlik gelirin telafisini karşılayan nakdi avans ödemeleri, iş sezonunda hanenin tamamının emeğinin aracılıktan "hanereisliğine" yükseltilen çavuş hanereisi lehine ipotek altına alınmasını sağlamaktadır. Bu ipotek, çavuşa çalışma bölgesindeki işverenler için işçi temininde kolaylık ve ücret pazarlıklarında avantaj sağladığı gibi (Kaleci 2004:49) aracıyı hanereisi konumuna yükselterek aracılı̆̆ının meşruluğu ve devamını da mümkün kılmaktadır. Bu hane formu, aynı zamanda Wallerstein ve arkadaşlarının tartıştı̆̆ hane kavramlaştırmasına eklenebilecek yeni bir hane formunu oluşturmaktadır. Aracı haneler, birbirleri ile kanbağı içermeyen ama maximum fayda üzerinden aynı maça farklı zorunluluklar nedeniyle hizmet veren bireylerden oluşmatadır. Özellikle geçici tarım işçiliğine çıkan kişilerin belirli bölgeden ve süreklilik halinde olduğunu düşündüğümüzde, yeni hane formu içerisinde avans ilişkilerinin varlığını ve belirleyiciğini daha iyi kavrayabiliriz.

Ek olarak bizim açımızdan işgücünün sürekliliği yanında daha da önemlisi, önceden avans sitemi ile kurulmuş üretim ilişkilerinin zorunlu çalışmaya çok daha kolay dönüşsürülmesi ve bu çalışmalarda artıdeğere el koymanın farklı türlerine işlerlik kazandırmasıdır. Bir başka deyişle, bu durum sömürünün derecesinin aracı tarafindan aracı lehine belirlenmesinden işçinin hali hazırda çalıştı̆̆ aracıdan başka kimse ile çalışamaz duruma gelmesine ve yapılan işlerin nasıl yapılması gerektiğine kadar bir dizi anlaşma ve çalışma koşullarında somutlaşmaktadır. Avans sistemi aynı zamanda iş̧̧iler üzerinde aracının sosyal nüfuzunu da artırmaktadır.

Adıyamanlı Sultan Hanım bu borçlanma durumunu şöyle açıklıyor:

... eşim dört milyara inek aldı. Görümceme de altın borcumuz var Eşim iş̧̧i. Çavuştan 300 lira da borç aldık onu ödemek için geldim. ....Yok kocam gelmedi. Beni çavuşa kattı. Uzaktan 
akrabamız olur çavuş (Sultan, 35, Konaklı).

Sonuçta aracı hanelerin varlığı işçilerin emekleri üzerindeki kendi kontrollerini devretmelerine ve emeğin özgür formdan çıkmasına yol açmış olur. ${ }^{5}$ Buna ileride fiyat belirlemesinde aracılık kısmında yeniden değineceğiz.

Boratav, küçük çiftçiliği aile emeğine dayalı tarımsal yapılar üzerinden, ve capitalist çitçiliği de ücretli işgücüne dayalı tarımsal yapılar üzerinden tanımlamaktadır. Geçici tarım işgücünün aracılar üzerinden kontrolünde Boratav iki önemli noktanın altını çizer: Birincisi, söz konusu ilişkilerde emek kapitalist üretim biçiminde öngörüldügü gibi özgür değildir (Boratav, 2004). Tarım aracılarının emeğin kullanımı üzerinde denetimi söz konusudur. İkincisi ise söz konusu üretim ilişkisinin yarı feodal bir nitelik gösteriyor olmasıdır. Tarım aracıları avans ilişkisi dolayımıyla kapitalist çiftçilerin kontrolüne girer.

“Ancak ücretli işgücü kullanımı her zaman, mutlak kapitalist çiftçilik göstergesi sayılmamalıdır. Bir tarımsal yapıda ücretli işgücü, aile emeğine dayalı işgücünden daha düşük ise, bu durumda, tarımsal yapı kapitalist olarak değerlendirilmemelidir (Boratav, 2004: 41)." Geçici tarım tam da bu anlamıyla capitalist bir formda yürütülmekte fakat yöntemi üretim ilişkilerinin oldukça dişında kalmaktadır. Bu ilişkileri bir bütün olarak değerlendirdiğimizde, Boratav, tarımsal işgücünün, aracılar yoluyla, kapitalist çiftçilerin denetimi altında olduğunu ve kadın emeğinin dahilinde kurulan ilişkilerden çok, İşveren-Çavuş ve hane reislerinin ilişkisinden oluştuğuna destek verir (Boratav, 2004: 41-42). Bu durum, ileriki sayfalarda özellikle kadın emeğinin dolayımı tartışmasında daha çok belirginleşecektir.

\section{b. Ulaşımın Să̆lanması}

Çavuşların aracı pozisyonlarını güçlendiren ve bir çok örnekte gördüğümüz gibi kaçınılmaz kılan bir başka işlev, geçici tarım işçilerinin çalışma bölgelerine gidişlerini tek başlarına organize edememeleri ile doğrudan ilintilidir. Bu engel, en başta geçici tarım işçilerinin bir hane olarak aracıların etrafında örgütlenmelerini ve ulaşımlarının aracıların dolayımıyla yapmalarını zorunlu kılmaktadır.

$\mathrm{Bu}$ sorunun detaylı bir devamı olarak ortaya çıkan bir başka sorun ise konaklama alanından çalışma alanına ulaşım sorunudur. Burada aracıların ulaşım altyapısının kullanılması kaçınılmaz olarak ortaya çıkmaktadır ve bu alt yapının kullanımı ücretsiz değildir. Ulaşım ücreti, çalışanların günlük ücretleri üzerinden kesilmektedir. Ulaşım aracının satın alınma maliyeti, işçilerin kazancı ile karşılanamayacak kadar yüksektir. Veya bir başka deyişle alınan ücretler, kendilerini tarlaya götürecek olanakları yaratacak kadar yüksek değildir. Bu aynı zamanda haneyi çavuşun aracılığına zorunlu kılmaktadır. Görüşme yapılan bir çok kişi ve hane reisi, araç temin edilmesi durumunda çavuştan ayrılacaklarını ifade etmişlerdir. Çavuş ile çalışmayan hanelerin tamamının kendi ulaşım araçlarına sahip olmaları, ulaşım aracının bağımsız çalışmadaki önemini göstermektedir.

\section{c. İhtiyaçların Karşılanması}

Geçici tarımda belirgin olan ihtiyaçlar sadece memleketlerinden çalışacakları illerde konaklama alanlarına ve çadır alanlarından çalışılacak tarlalara gidiş-geliş ile sınırlı değildir. Ayrıca geçici konaklamanın tamamında temel ihtiyaçların il/ilçe merkezlerinde giderilmesiyle de ilgilidir. Bu konu ile ilgili olarak mevsimlik tarım işçisi olarak gelmiş ve hanede erkek

\footnotetext{
${ }^{5}$ Emeğin kontrolü için bakınız ( Çınar ve Lordoğlu, 2011:435, Erdoğan, 2010)
} 
olmadığ 1 veya ulaşım aracına sahip olmadığı için ihtiyaçlarını karşılamakta zorlanan ve araç teminini tek başına karşılayamayan tarım işçisi Urfalı Leyla şunları söylemiştir:

Biz çavuşa bağlı olmak istemiyoruz fakat arabamız yok. Mecburen çavuşa bağlanıcıyık... niye, çünkü arabamız yoktur. Çavuş iki aileyi alır götürür çalıştırır paralarını verir. (Leyla 40, Ovacık kasabas1)

Burada bağımlılığın hem nedeni hem de devamı olarak çalışan işçiler ihtiyaçları için gerekli ürünleri temin edebilecekleri yerel pazarlara ulaşımda sorunlar yaşamaktadırlar. Sorunsuz ihtiyaç temini demek, işçilerin çalışma süresince çavuşların aracılığına bağlanmak anlamına geliyor. Bu aracılık hizmeti çavuşlara bölgedeki market ve toptancılardan her türlü ihtiyaç mallarını ucuza mal alarak işçilere normal fiyatlardan satması sonucu ek gelir elde etme imkanı vermektedir.

Hüseyin çavuş işin detaylarını şöyle anlatmaktadır:

Burada marketler için önemli biriyim. 150 kişinin tüketimini ben yönetiyorum. Hangisi indirim verirse onunla anlaşıyorum. Haftada bir gün markete araba gönderiyorum. İşçim ihtiyacını gidip alıyor, yazdırıyor adına. İşçinin ücretinden düşüyorum masrafını. Ben de ay sonu markete gidip \%10 indirimle ödememi yapıyorum. Bir tür ticaret bu da (Hüseyin Çavuş, Konakl1).

$\mathrm{Bu}$ gelir sonucu, çavuşlar ısrarlı bir şekilde bu aracılık hizmetini sürdürmeye ve paraya veya emeğin daha fazla ipoteğine dönüştürdükleri bu hizmet hakkını korumaya yönelmektedirler. Zaman zaman kendisi üzerinden mal alımı yapmayan işçileri işe çıkarmada veya sağlık sorunları ortaya çıktığında onları doktora götürme konusunda gönülsüz davranarak kendinden mal almayan işçisini cezalandırabileceğini muhatabına göstermektedir (Hüseyin çavuşun notlarından). Bireysel olarak tüketimi herhangi bir kişi veya ailenin kendi kontrolünde tutması, aracılık hizmetlerinin bir bütün olarak sistemli hale gelmesi nedeniyle çok mümkün olmamaktadır. Bu bütünsel sistem işçileri çadırdan tarlaya olan bir sınırlılığa hapsetmekte ve işçilerin bölge hakkındaki bilgilerinin veya işverenler ile doğrudan ilişki için gerekli sosyal sermayenin birikimine engel olmaktadır. Bir başka deyişle, zorunluluktan dolayı ihtiyaçların aracılar tarafından karşılanması, geri dönüşte ihtiyaçları karşılandıkça hanelerin aracılara bağımlılı̆̆ının daha da artmasına neden olmaktadır.

\section{d. Konaklama Altyapısının Temini}

Konaklama sorunu iki alt başlık altında incelenebilir. İlki konaklama alanlarının tespiti ve temini meselesidir. Zira çalışma amaçlı gelen haneler, çadırlarını istedikleri yerlere, özellikle de su yakınlarına veya tarla kenarlarına kuramamaktadırlar (İşveren, muhtar ve Çavuş’un ortak notlarından). Öncelikle kalınacak yerlerin tespit edilmesinde çavuşların işverenlerle, yerel halkla ve yerel yönetimlerle bir dereceye kadar kurumsallaştırdığı ilişkileri aracılara büyük avantajlar sağlamaktadır. Bölgede bir kez konaklama alanının tespiti yapıldıktan sonra bu alan genişletilmesi veya değiştirilmesi mümkün görünmemektedir. Çalışma bölgesine kendi olanakları ile sonradan ulaşan hanelerin konaklama alanlarında su ve tuvalet gibi ortak kullanım alanlarına yakın olmaları pek mümkün olmamaktadır.

Öte yandan, konaklamada kullanılacak çadırların temin edilmesi de işçi çavuş ilişkisinde zorlayıcı bir belirleyiciliği öne çıkarmaktadır (İşveren, muhtar ve Çavuş'un ortak notlarından). Konaklı kasabası gibi altyapısı ve çadırları hazır olan yerlerde yerel yönetim ile kurulan ilişkilerin karşılığı ekstra çadır ve çadır yeri olarak aracılara geri dönmektedir. Bu avantajlı durum, sonradan gelen hanelerin yerleşmesinde farklı güçlükleri de beraberinde getirmektedir. 


\section{Aracılık İlişkilerinin Sosyal Formları a. Sosyal Bağların Etkisi}

Kurulan avans ilişkileri elbette aracılık hizmetlerinin biricik sonucu veya nedeni değildir. Önemli etkenlerin başında, son safhada çavuşu hane reisliğine yükseltecek olan memlekette ikamet eden işçi hanelerinin çavuşa karşı bağımlılığı, sadakati, bir sosyal çevre içerisinde dayanışma ağlarının parçası olması gibi mekanik ilişki kodlarının belirleyici olduğu akrabalık, hemşericilik, komşuluk vb. gibi ilişkilere birincil derecede sahip olması da gelmektedir. Çınar ve Lordoğlu (2011: 435) bu bağımlılık gerekçelerini, sömürü ilişkilerinin kurulmasındaki birincil ilişkiler olarak değerlendirmektedir. Zorunlu olmadığı ve karşılığın/maliyetin ödenmediği durumda bile Çavuş için yemek hazırlayan Adıyamanlı Melek'in çavuşuna karşı saygı içerisine gömülü olan tek taraflı duygusal emek ilişkisi bu duruma iyi bir örnektir:

Yemek yaptık, çavuşuma ayıp olur. Şimdi olmaz yani... kızlar hemen bir tabak hazırlayın güzelce süsleyin de çavuşuma verelim (yan çadırda oturan kadın işçilerden Melek, 16, Konakl1).

$\mathrm{Bu}$ tür kan ve sosyal bağlar, geçici işçi hanelerinin çavuş merkezli oluşumunu açıklarken, kısmen çoğu geçici iş̧̧inin ama özellikle de kadın işçilerin, zorun rızaya dönüştürülmesi üzerinden istemedikleri halde zorunlu gelişini de açıklamaktadır.

Adıyamanlı Neslihan'ın, çavuşa bağlanma konusunda söyledikleri önemlidir:

Bakmayın böyle çalışıyoruz çavuşumuz dayım olur. Fakat ben bile güvenmem... ama yine de çalışmaya geliyoruz. (Neslihan, 22,Konaklı)

Burada ortaya çıkan gerçek, hanelerin sadece doğrudan kan bağı ile değil ekonomik bağlar ile de kurulabiliyor olduğudur. Aracıların kurulu sosyal ağlar aracılığıyla mevsimlik tarım işçiliğine gelmek istemeyen aileleri zorunlu kıldığı en çok karşılaştığımız örneklerdendir.

Babam ile Çavuşun arası iyidir. Kışın bize yardımcı olur maddi olarak. Babam da çavuşun elemana ihtiyacı olduğunda bizi katar yanına...yok para almayız, babamla hesaplaşırlar. Üç kardeşim de burada (Hatem 21, Konakl1).

Konaklı kasabasında görüştügüümüz mevsimlik tarım işçilerinin büyük çoğunluğu, patates hasat döneminin sonbahar ortalarında soğuk hava koşullarına denk gelmesine rağmen zorunlu olarak geldiklerini söylemişlerdir.

\section{b. Lokal Bağların Etkisi}

Geçici tarım işçiliği üzerinde ayrımcı bir sorun olarak kendisini dayatan "Konaklama Alanlarının Tespiti ve Yerleşkenin Kuruluşu" sorunu, bizim çalışmamızda da sıklıkla beliren bir durumdur. Çavuşların kurmuş olduğu lokal ilişkiler, kısmen de olsa bu tür engelleri en aza indirgeyebilmektedir. Tarımsal alanlarda veya yakınlarında çadır konaklaması istemeyen işverenler ve yerel köylüler, çavuşlar ile olan ilişkilerin yoğunluğuna bağlı olarak esnek davranabilmektedirler. Normal gelen işçiler için, Belediye tarımsal niteliği olmayan ama tarımsal alanlara da oldukça uzak olan bozkır alanlarda çadır yerleşkeler oluşturmuşlardır. Kendi imkanları ile gelen işçilerin bu alanlar dışında konaklamaları mümkün olmamaktadır (İşveren, muhtar ve Çavuş’un ortak notlarından). Bu ikili uygulamanın nedeni, kurulan sosyal sermaye ilişkilerinde geliştirilen güven olgusunun bilinen ve bilinmeyen kişilere karşı farklı sonuçları ile ilgilidir. Sosyal sermaye dışı durumlarda, bu çadır yerleşkelerin, yerel halkın ahlaklarına ve bütünklüklerine zarar verdiği düşüncesi belirleyici olmaktadır. 


\section{c. Bölgeye Dair Bilgi Eksikliğinin Etkisi}

Geçici tarım alanlarına ulaşım konusunda kısmen de olsa bir uzmanlaşma görülmektedir. Ana hatlar üzerinde geçici tarım işçilerinin kullanabilecekleri ve ulaşım alt yapısı olarak hizmet veren mekik sistemi bulunmaktadır. Belirli zamanlarda ve belirli toplanma yerlerinden yolcuyu alarak ana hatlarda işçilerin gidecekleri yerlere oldukça yakın noktalara yolcu taşımacılığı son dönemlerde oldukça gelişmiştir. Fakat ulaşımdaki bu gelişme ve uzmanlaşma geçici tarım işçilerinin sezonluk göçünde aracılardan bağımsız hareket etmelerini olanaklı kılmamaktadır. Bunun en önemli nedeni, çalışmak amaçlı sezonluk göç eden işçilerin gelebilecekleri bölgeler hakkında en temel bilgi ve tecrübeden yoksun oluşlarıdır. Daha da önemlisi önce çalışılan bölgede dahi yeniden çalışmak amacıyla tekrarlanan göçte dahi bu durum görülmektedir. Bunun en önemli nedeni, aracılık sisteminde işçilerin karar vericiler olarak üretim ilişkilerinin ve dahi antlaşmaların dışında tutulması ve her türlü ihtiyaçlar temininde aracı çavuşun sürekli olarak devrede kalma konusunda baskı oluşturmasıdır. Bilgi birikimine uygun olmayan ilişkilerin varlığı, işveren ile kurulacak güven ilişkisini belirleyecek olan sosyal sermayenin de gelişmesine engel teşkil etmektedir. Çavuşların bağımsız emek ile sermaye arasındaki güven ilişkisinin gelişmesine engel olma biçimi, kapitalist bir formda geçici tarım işçiliğinin kurumsallaşması olarak da ele alınabilir. Bu kurumsallaşma geçici tarım alanındaki bileşenlerin bir işbölümü çerçevesinde mutabakat oluşturması olarak somutlaşmaktadır.

\section{Emek Değerinin Belirlenmesinde ve Kullanımında Mutabakat Bileşenleri}

Geçici tarım işçiliğinde özellikle kadın emek değerinin sabitlenmesinin klasik anlamda serbest piyasa koşullarına bağlı olarak gerçekleşmediği en somut haliyle görülmektedir. Bir başka deyişle çalışmamızın bulgularından hareketle, emek değerinin belirlenmesinde emek bileşeninin hiç bir etkisi bulunmamaktadır. Bu durum işin klasik olarak taşeronlaştırılması mantığının daha üst bir formunu oluşturmaktadır. Emeğin kontrolünü pekiştiren farklı ilişkilerin ücret belirlenmesinden önce kurulu olduğunu düşünmekteyiz. $\mathrm{Bu}$ ilişkiler incelendiğinde, ilk önce emek değerinin sabitlenmesinde emeğin asıl bileşenin (özellikle kadın emeği) dışında Sermaye, Aracı-çavuş- ve Belediye Başkanından oluşan bir üçgen karşımıza çıkmaktadır. İkinci olarak, emek değerinin sabitlenmesinde adı değil ama kendisi bir faktör olarak olmayan kadın emeğinin kullanımı; aracı hane veya hane reisliği kapsamında emeğin değerinin markette belirlenmesinden bağımsız bir süreç olarak organize edilmektedir. Aracının bağlantı sağladığı ve temsil ettiği sermaye ile işçilerin arasında yazılı olmayan çalışma sözleşmesi, üzerinde mutabık kalınmış bir piyasa değeri olan ücret üzerinden oluşturulmamaktadır. Bu belirlenme, işçi-sermaye arasında görülmekle birlikte aracının emek üzerinde sosyal bir baskı aracı olarak konumlanmasından kaynaklanmaktadır. Dolayısıyla "aracıların, salt piyasa odaklı iş gücünü kontrol etmelerinden dolayı işveren karşısında işçilere göre daha güçlü bir konumda bulunduğu tespiti ( Çınar ve Lordoğlu, 2011:437)" çalışmamızda doğru olmakla birlikte yeterli bir karşılık bulmamaktadır. Kadın emeğinin, ücretin belirlenmeden işe koşulması ve üretime katılması, stratejik ve rasyonel davrandığı iddia edilen patriarkal bir hane içerisinde emeğin doğrudan sosyopolitik kontrolünün bir sonucu olarak değerlendirilmektedir. Sürecin daha çok aracıların işlevsel olduğu sosyopolitik bir düzenekte yürümesi, aracıların emek üzerinde bir baskı aracı olarak gücünün bulunduğunun bir kanıtıdır. Aracının fiyat belirlenmesindeki rolü, kendi alacağı komisyonunun belirlenmesinin de bir fonksiyonu olduğu için, işçiden daha çok işverenle hareket edeceğini öngörmek yanlış olmayacaktır.

Ücreti konuşmadan önce işe başlamalarının hakkında Urfalı Musa şu şekilde anlatmıştır: 
Dinç, Ö. A. (2020), "Kırsal Emeğin Dolayımında Aracı Formlar ve Egemenlik İlişkileri: Dünya Ekonomisinde Hane ve Emek Tartışması”, Politik Ekonomik Kuram, 4 (2), 310-329.

Ne gerek var nasıl olsa oturulur konuşulur

Emeğin kontrolü olarak görülebilecek bu fiyatsız çalışma ilişkisi işin denetiminde çok daha somut olarak gözlenebilmektedir.

Bizler çapada da çalışırız. Fasulyede çalışırız. Çavuş gelir inceler bakar eğer beğenmezse tekrar yaparız zaten iyi çapa yapılıp yapılmadığı hemen bir bakışta belli olur. Fasulyede de ip gibi dümdüz çizeceksin. Aralarına traktör girecek kadar boşluk olacak. Kalmayacak haa dikkat etmek gerek. Diyelim ki çavuş geldi baktı çapa güzel olmamıştır bütün o tarlayı hiç para almadan tekrar çapalarız (Musa, yaş 50,Ovacık Kasabası).

\section{Sonuç}

Farklı kuşaklarda bulunan farklı özelliklerdeki işgücünün farklı şekilde sömürüldüğü tezi Wallerstein ve Hopkins'in dünya-sistemi yaklaşımını geliştirmelerindeki en önemli rasyonalite olarak karşımıza çıkmaktadır. Bu yaklaşım, kapitalizmin kuruluşundan bu tarafa ortaya çıkan dönemsel krizlerin (Kondradiev döngülerinin) aşılmasını ve kapitalizmin beş yüzyıldır devamını, kapitalist ilişkilerin farklı coğrafyaların kapitalist Dünya-ekonomi'sine entegre edilmelerine ve bu coğrafyalarda derinlemesine nüfuzuna bağlamaktadırlar ( $\mathrm{K}$. Terence Hopkins \& Wallerstein, 1982; I. Wallerstein, 1984).

Sistemin genişlemesi, öncelikle çevrede ekonomik aktivitelerin merkez ekonomilerin lehine örgütlenmesi sayesinde çevrenin merkeze entegrasyonu ile mümkün olmaktadır. Çevrenin çevre olarak sürekliliği, merkez ekonomiler açısından farklı formlarda üretim ilişkilerine başvurabildikleri bir çıkış yolu olarak görülmüş ve sistemin ekonomik darboğazları aşmasında ve sistemin sonsuz sermaye birikimi için genişlemesinde kilit rol oynamıştır. Genişlemenin olabilmesi için öncelikle Dünya-ekonomi'si içerisinde ihtiyaca bağlı olarak üretim yapabilecek bir ekonominin varlığı gerekmektedir. İkinci olarak bu üretimi organize edebilecek işgücünün kapitalist olmayan üretim formundan kapitalist üretim ilişkisine transferi ve emeğin kontrolünün artı değere el koyan sermaye sınıfina devredilmesi gerekmektedir: işgücünün doğrudan sömürülmesi için proleterleşmesi. Son olarak çevrede üretilen artı değerin merkez ekonomilere akışını ve bu akışın güvenliğini sağlayacak politik yapının-devletin devler-arası sisteme çevre devlet olarak girmesi gerekmektedir. Bu süreç çevrede yönetimsel faaliyetlerin merkez ülkeler lehine merkezileşerek belirli egemenlik alanlarında yaşayan insanların milliyet, etnisite, dil, din veya ırk altında yönetilmesini gerektirmektedir.

Söz konusu eklemlenmenin sağlıklı olabilmesi; sınıfsal bir ilişkiden daha çok sosyal bir form olarak bir araya gelen Hanelerin varlığı ile mümkün olmaktadır. Özellikle geçici tarımda ucuz emeğin arzı ve emeğin kontrolü, tam da hanelerin varlığı, ve aracilığı ile mümkün olabilmektedir. Mevcut Hanelerin olmadığı veya geçici tarım işçiliğinde optimum fayda ve kar oranlarını karşılamadığ durumlarda aracılar üzerinden "geçici hanelerin" oluşturulması da kaçınılmazdır. Bu haneler geçici ve aracı haneler olarak dünya-sistemi literatüründe daha fazla örnekleri ile çalışılmalıdır.

$\mathrm{Bu}$ geçici ve aracı hanelerin üyeleri; üretim ilişkilerinin en önemli ve eşit olarak kabul edilmeyen bileşeni olarak karşımıza çıkmaktadır. Bu durum sadece üretici emek olarak değil aynı zamanda yeniden üretimi düzenleyen emek olarak da geçerlidir. Bu yeniden üretim sürecinin sorumluluğunu çoğu zaman kültürel ve toplumsal bir biçim üzerinden okuyanlar da mevcuttur. Fakat bizim temel iddiamız yeniden üretimin içerisinde yer aldığı özel alan, ekonomik ilişkilerin üzerinde gelişen kamusal alandan bağımsız olarak değerlendirilemeyeceği üzerinedir. Geçici tarım işçiliğinde, özel alan kamusal alanın dışında yer almadığı gibi sıradan bir uzantısı da değildir. Özel alan olarak gördüğümüz ilişkiler, bizzat ekonomi üzerinden iktidar ilişkilerinin devamlılığını sağlayan üretim ilişkileri alanıdır. Erkeğin hane emeğini dolayısıyla kadın ve çocuk emeğini doğrudan kontrol ettiği ve yönettiği bir alandır. 
Dinç, Ö. A. (2020), “Kırsal Emeğin Dolayımında Aracı Formlar ve Egemenlik İlişkileri: Dünya Ekonomisi’nde Hane ve Emek Tartışması”, Politik Ekonomik Kuram, 4 (2), 310-329.

\section{Kaynakça}

Altan, Feride. (1987). Tarımsal işletmelerin yeniden tabakalandırılması üzerine bir deneme. 11 . Tez, Türkiye'de Tarım Sorunu, İstanbul: Uluslararası Yayıncılık, 35-45.

Arghiri, E. (1972a). Unequal exchange: A study of the imperialism of trade. New York \& London: Monthly Review Press.

Aydın, Zülküf, (2002). The new right, structural adjustment and Turkish agriculture: rural responses and survival strategies. The European Journal of Development Research, 14(2), 183-208.

Benek, S. ve Ökten, Ş., (2011). Mevsimlik tarım işçilerinin yaşam koşullarına ilişkin bir araştırma: Hilvan ilçesi (Şanlıurfa) örneği. Gaziantep Üniversitesi Sosyal Bilimler Dergisi, 10(2), 653 -676.

Bernstein, Henry, (2009). Tarımsal değişimin sınıfsal dinamikleri. İstanbul: Yordam Kitap.

Boratav, Korkut, (2004). Tarımsal yapılar ve kapitalizm. Ankara: İmge Kitabevi.

Candan, E. ve Özalp Günal, S., (2013). Tarımda kadın emeği. Tarım Ekonomisi Dergisi, 19(1), 93-101.

Chase-Dunn, C. (1983). The Kernel of the capitalist world-economy: Three approaches. In W. Thompson (Ed.), Contending Approaches in World-System Analysis (pp. 35-78). Beverly Hills: Sage.

Chase-Dunn, C. (1991). Global Formation, structures of the World-Economy. Oxford: Basil Blackwell.

Daly, M. (1989). Woman and poverty. Dublin: Attic Press.

Dedeoğlu, S. (2018). Tarımsal üretimde göçmen işçiler: Yoksulluk nöbetinde yoksulların rekabetine. Çalışma ve Toplum, 1, 37-67.

Ellis, F., (2008). Peasant economics: Farm households and agrarian development. cambridge; New York, NY, USA: Cambridge University Press.

Emmanuel, A. (1972). Unequal exchange: A study of the imperialism of trade. New York: Monthly Review Press.

Erdoğan, G. (2010). Mevsimlik gezici tarım işçilerinin çalışma ve sosyal hayatlarının iyileştirlmesi projesi (METIP). Işs Sağlı̆̆l ve Güvenliği Dergisi, 10(48).

Erdost, Muzaffer İlhan, (1988). Kapitalizm ve tarım. Ankara: Onur Yayınları.

Esin CANDAN, and Semiha ÖZALP GÜNAL (2013). Tarımda kadın emeği. Tarım Ekonomisi Dergisi, 19(1), 93-101.

Friedman, K. (1984). Household as income -pooling unit. In I. Wallerstein, J. Smith, \& H.-D. Evers (Eds.), Households and the World Economy (pp. 37-56). California: Sage Publications.

Geçgin, Ercan. (2009). Ankara-Polatlı örneğinde dışlanma açısından mevsimlik tarım işçiliğii. Ankara. Ankara Üniversitesi Sosyal Bilimler Enstitüsü Dergisi, 1 (1), 3-35. 
Dinç, Ö. A. (2020), "Kırsal Emeğin Dolayımında Aracı Formlar ve Egemenlik İlişkileri: Dünya Ekonomisinde Hane ve Emek Tartışması”, Politik Ekonomik Kuram, 4 (2), 310-329.

Gülçubuk, Bülent. (2012). Tarımda çocuk emeği sömürüsü ve toplumsal duyarlılık. Çalışma ve Toplum, 2, 75-94.

Güneş, Fatime. 2020. Mevsimlik işçilikte kadın emeği. Türkiye Tohumcular Birliği Dergisi, 16-19 https://www.turktob.org.tr/upload/dergi16/16-19.pdf.

Hopkins, K. T. (1982a). Notes on class analysis and the World-System. In T. Hopkins and I. Wallerstein (Ed.), World System Analysis: Methodological Issues (pp. 83-91). New York: Sage publications.

Hopkins, K. T. (1982b). The Study of the Capitalist World-Economy:Some Introductiory Considerations. In T. Hopkins and I. Wallerstein (Ed.), World System Analysis: Methodological Issues (pp. 9-39). New York: Sage publications.

Hopkins, K. T., \& Wallerstein, I. (1977). Patterns of Development of the Modern WorldSystem. Review, 1, 111-145.

Hopkins, e., \& Wallerstein, I. (1982). Patterns of development of the modern World-System. In T. Hopkins and I. Wallerstein (Ed.), World System Analysis: Methodological Issues (pp. 41-83). New York: Sage publications.

İlkaracan, I. and Tunal1, I., (2010). "Agricultural Transformation and the Rural Labor Market in Turkey" in Karaçınar, B., Adaman, F. and Ozertan, G. Rethinking structural reform in Turkish agriculture: Beyond the World Bank's strategy. New York: Nova Science Publishers.

Kilıçbay, M. A. (1985). Witold Kula ve 'Feodalizmin Ekonomk Teorisi' üzerine. In W. Kula (Ed.), Feodalizmin ekonomk teorisi (pp. VII-XVII). Ankara: Birey ve Toplum Yayınları.

Kula, W. (1985). Feodalizmin ekonomk teorisi. Ankara: Birey ve Toplum Yayınları.

Payne, S. (1991). Women, health and poverty: An introduction. Hemel Hempstead: Harvester Wheatsheaf.

Ploeg, Jan Douwe van der. (2008). The new peasantries: Struggles for autonomy and sustainability in an era of empire and globalization. UK-USA Eartscan Pub.

Razavi, S. (1999). Export oriented employment, poverty and gender: contested accounts. Development and Change, 30, 653-683.

Ruspini, E. (1999). the contribution of longitudinal research to the study of women's poverty. Quality and Quantity, 33, 323-338.

Semerci, U.P., Erdoğan, E. ve Kavak, S., (2014). Mevsimlik tarım işçiliği araştırma raporu 2014. Hayata Destek Derneği. http://hayatadestek.org/media/files/raporHDD.pdf (Erişim tarihi: 30.11 .2015 )

Sirman, N., (1991). Gelişme sürecinde kırsal kesim kadını yaklaşımlar ve sorunlar, kırsal kesimde kadının statüsü: Sorunlar ve çözüm önerileri. Aralık 1990, ILO-TKV Danışman Toplantısı Raporları, Ankara, 16-29.

Standing, G. (1989). Global feminization through flexible labor. World Development, 17(7), 1077-95.

Toksöz, G. (2012). Kalkınmada kadın emeği. İstanbul: Varlk Yayınları. 
Tomich, D. W. (1990). Slavery in the circuit of sugar : Martinique and the world economy, 1830-1848. Baltimore: Johns Hopkins University Press.

Uysal, H.T. ve Kesim, E., (2014). Mevsimlik işçi örgütlenmelerinde örgüt içi ve örgüt dış1 faktörlerin işçi performansına etkisi: Fındık işçilerine yönelik bir araştırma. Yönetim ve Ekonomi Araştırmaları Dergisi, Sayı 22, 152-173.

Walby, Sylvia. (1989). Theorising patriarchy. Sage.

Wallerstein, I. (1979). The Capitalist-World-Economy. Cambridge: Cambridge University Press.

Wallerstein, I. (1982). World-Systems analysis: Theoretical and interpretative issues. In T. Hopkins and I. Wallerstein (Ed.), World System analysis: Methodological issues (pp. 91104). New York: Sage publications.

Wallerstein, I. (1984). Patterns and prospectives of the capitalist World-Economy. Contemporary Marxism, 9, 59-70.

Wallerstein, I. (2004). World-Systems analysis: An introduction. Durham: Duke University Press.

Wallerstein, I. (2016). The Itinerary of World-System analysis; Or how to resist becoming a theorty. In Uncertain worlds: World-systems analysis in changing times (pp. 195-219). New York: Routledges.

Wallerstein, I., Martin, W. G., \& Dickinson, T. (1982). Household structures and production processes: Preliminary theses and findings. Review (Fernand Braudel Center), 5(3), 437458.

Wallerstein, I., \& Smith, J. (1992a). Creating and transforming households: The constraints of the World-Economy. Cambridge: Cambridge University Press.

Wallerstein, I., \& Smith, J. (1992b). Household as an institution of the world economy. In I. Wallerstein \& J. Smith (Eds.), Creating and transforming households: The constraints of the World-Economy (pp. 3-27). Cambridge: Cambridge University Press.

Wallerstein, I. M. (1974). The rise and future demise of the world capitalist system: Concepts for comparative analysis. Comperative Studies in Society and History, 16, 390.

Yıldırak, N., Gülçubuk, B., Gün, S., Olhan, E. ve Mehmet, K., (2009). Türkiye'de gezici ve geçici kadın tarım işçilerinin çalışma ve yaşam koşulları ve sorunları. http://arsiv.agri.ankara.edu.tr/economy /1189_ 1205793629.pdf (Erişim Tarihi: 25.11.2015) 